\title{
The effect of naked oats (Avena nuda L.) used in feeding gilts on their sexual activity
}

\author{
B. Szostak ${ }^{1}$, A. Stasiak ${ }^{2}$, and Ł. Przykaza ${ }^{3}$ \\ ${ }^{1}$ Institute of Animal Nutrition, Faculty of Biology and Animal Breeding, University of Life Sciences in Lublin, \\ Lublin, Poland \\ ${ }^{2}$ Department of Pig Breeding and Production Technology, University of Life Sciences in Lublin, Lublin, Poland \\ ${ }^{3}$ Department of Neurosurgery, Medical Research Centre PAS in Warsaw, Warsaw, Poland \\ Correspondence to: B. Szostak (bogdan.szostak@up.lublin.pl)
}

Received: 3 September 2014 - Accepted: 5 November 2014 - Published: 4 March 2015

\begin{abstract}
The study was carried out on 180 Polish Landrace gilts. Three gilts were selected from each of 60 litters. When their body weight had reached about $30 \mathrm{~kg}$, the gilts were divided into three groups, two experimental and one control, with 60 individuals per group. The mixture fed to the experimental groups contained $40 \%\left(\mathrm{D}_{1}\right)$ and $20 \%\left(D_{2}\right)$ naked oats of the Akt variety. Sexual activity was observed in the gilts during the first, second and third oestrus. The occurrence of the standing reflex was tested twice a day, in the morning and afternoon, and its duration was determined by timing the positive reaction to a boar, to touch and to mounting. The first oestrus occurred earliest in the experimental gilts (group $D_{1}$ ) at an average age of 178.2 days, i.e. 8.7 days earlier than in the control group. Analysis of the $17-\beta$-estradiol level in the blood serum of the experimental gilts showed that the feed rations containing naked oats had a beneficial effect on the secretion of this hormone.
\end{abstract}

\section{Introduction}

A very important period in the reproductive life of gilts is the onset of oestrus and ovulation, indicating that the gilts have reached sexual maturity. Sexual maturity in gilts can be accelerated and certain disorders eliminated by means of oestrus-stimulating techniques such as an intensive diet high in calories, protein and vitamins; a change of room or pen; contact with a boar; keeping gilts in pens near a boar; the use of pheromones; allowing the gilts to use paddocks; or administering oestrogen (Cronin et al., 1983; Hemsworth, 1987; Levis, 2000; Evans and O'Doherty, 2001; Gordon, 2004; Peltoniemi et al., 2005). A temporary lack of libido and oestrus may be due to a lack of exercise, flaws in the manner in which the animals are kept, and, above all, by quantitative and qualitative nutritional deficiencies (Levis, 2000). Naked oats have higher energy and protein value than other grains considered to be the best for feeding monogastric animals (Petkov et al., 2001). The amino acid composition of oat protein is beneficial because the content of almost every exogenous amino acid is higher than that found in wheat (Kosieradzka and
Fabijańska, 2001). In naked oats there is a predominance of globulin in comparison to prolamin and glutenin. Naked oats have exceptionally high fat content, from 6 to $10 \%$ d.w. (Piech et al., 2003; Pisulewska et al., 2011). The lipid composition of naked oats has a predominance of unsaturated fatty acids (UFAs), which account for over $80 \%$ of the fat (Pisulewska et al., 1999). Compounds with powerful antioxidant properties have been identified in oat lipids (Peterson, 2001). Studies by Stasiak et al. (2000) and Mazur and Stasiak (2006) showed that feeding with mixtures containing naked oats had a beneficial effect on reproductive performance indicators in gilts and sows.

The aim of the study was to determine the effect of naked oats used in feed rations for gilts on their sexual behaviour.

\section{Material and methods}

The study was carried out on 180 Polish Landrace gilts kept on a breeding farm. Three gilts, with body weights of about $30 \mathrm{~kg}$, were selected from each of 60 litters. They were as- 
Table 1. Composition of mixtures for gilts.

\begin{tabular}{lrrr|rrr}
\hline Feed (percentage) & \multicolumn{3}{c}{$13-20$-week-old gilts } & \multicolumn{3}{|c}{ 20-26-week-old gilts } \\
& $\mathrm{D}_{1}$ & $\mathrm{D}_{2}$ & $\mathrm{~K}$ & $\mathrm{D}_{1}$ & $\mathrm{D}_{2}$ & $\mathrm{~K}$ \\
\hline Naked oats meal & 40.00 & 20.00 & - & 40.00 & 20.00 & - \\
Wheat meal & - & 20.00 & 40.00 & - & 20.00 & 40.00 \\
Barley meal & 37.35 & 37.30 & 37.25 & 42.35 & 42.30 & 42.25 \\
Soybean meal & 20.00 & 20.00 & 20.00 & 15.00 & 15.00 & 15.00 \\
2-Ca phosphate & 0.90 & 0.90 & 0.90 & 0.90 & 0.90 & 0.90 \\
Fodder chalk & 1.30 & 1.30 & 1.30 & 1.30 & 1.30 & 1.30 \\
Premixture L-lysine 50\% & 0.20 & 0.25 & 0.30 & 0.20 & 0.25 & 0.30 \\
NaCl & 0.25 & 0.25 & 0.25 & 0.25 & 0.25 & 0.25 \\
\hline Contents per 1 kg of mixture & & & & & & \\
& & & & & & \\
EM MJ & 13.04 & 12.90 & 12.76 & 13.04 & 12.90 & 12.82 \\
Crude protein (g) & 169.30 & 168.44 & 167.58 & 155.45 & 154.59 & 154.08 \\
Crude fat (g) & 40.21 & 30.35 & 20.49 & 40.11 & 30.26 & 20.36 \\
Lysine (g) & 9.20 & 9.19 & 9.18 & 8.19 & 8.10 & 8.15 \\
Methionine+cystine (g) & 5.84 & 5.74 & 5.63 & 5.48 & 5.38 & 5.29 \\
Ca (g) & 8.32 & 8.37 & 8.42 & 8.16 & 8.20 & 8.27 \\
P (g) & 6.15 & 6.06 & 5.97 & 6.05 & 5.96 & 5.87 \\
Na (g) & 1.21 & 1.20 & 1.19 & 1.19 & 1.18 & 1.17 \\
\hline
\end{tabular}

Table 2. Composition of mixtures for gilts.

\begin{tabular}{lrrr}
\hline Feed (percentage) & \multicolumn{3}{c}{ Gilts } \\
& $\mathrm{D}_{1}$ & $\mathrm{D}_{2}$ & $\mathrm{~K}$ \\
\hline Naked oats meal & 40.00 & 20.00 & - \\
Wheat meal & - & 20.00 & 40.00 \\
Barley meal & 48.50 & 48.45 & 48.40 \\
Soybean meal & 9.00 & 9.00 & 9.00 \\
2-Ca phosphate & 0.90 & 0.90 & 0.90 \\
Fodder chalk & 1.30 & 1.30 & 1.30 \\
Premixture L-lysine 50\% & - & 0.05 & 0.10 \\
NaCl & 0.30 & 0.30 & 0.30 \\
\hline Contents per 1 kg of mixture & & & \\
\hline EM MJ & & & \\
Crude protein (g) & 13.03 & 12.89 & 12.75 \\
Crude fat (g) & 138.03 & 137.18 & 136.32 \\
Lysine (g) & 39.98 & 30.17 & 20.32 \\
Methionine+cystine (g) & 5.98 & 5.97 & 5.96 \\
Ca (g) & 5.06 & 4.95 & 4.84 \\
P (g) & 7.69 & 7.73 & 7.78 \\
Na (g) & 5.73 & 5.64 & 5.55 \\
& 1.37 & 1.36 & \\
\hline
\end{tabular}

signed to one of three groups, two experimental and one control, with 60 individuals in each.

The gilts were fed complete mixed rations in amounts consistent with the norms given in "Swine Feeding Standards" (Normy Żywienia Świń, 1993). The mixture fed to the experimental groups contained $40 \%\left(\mathrm{D}_{1}\right)$ and $20 \%\left(\mathrm{D}_{2}\right)$ naked oats of the Akt variety. The composition and nutritional value of the mixtures is presented in Tables 1 and 2, adopting the values given in "Swine Feeding Standards" (1993) for barley, wheat and post-extraction ground soymeal. The chemical composition of naked oats was determined before the experiment on the animals was begun. The following were determined in the samples:

- content of crude protein, ether extract, crude ash and crude fibre according to AOAC (2000);

- content of mineral nutrients $\mathrm{Ca}$ and $\mathrm{Na}$ by atomic absorption spectroscopy (ASA) and total phosphorus according to Fiske and Subbarow (1925);

- protein amino acid content by ion-exchange chromatography in an automatic amino acid analyser;

- fatty acid composition by gas chromatography using a chromatograph (Varian GC3800, Varian Inc., Walnut Creek, CA, USA).

Sexual activity was observed in the gilts during the first, second and third oestrus. The occurrence of the standing reflex was tested twice a day, in the morning and afternoon, and its duration was determined by timing the positive reaction to a boar, to touch and to mounting. The intensity of oestrus symptoms was evaluated according to the scale developed by Stasiak (1996):

3 points - the gilts are very calm, manifest oestrus very clearly, react to the boar and to the mounting attempt for about 30-35 s;

2 points - the gilts are calm, manifest oestrus clearly, react to the boar and to the mounting attempt for about 20-25 s; 
Table 3. Age at each oestrus and sexual activity of gilts.

\begin{tabular}{lllllll}
\hline $\begin{array}{l}\text { Experimental } \\
\text { groups }\end{array}$ & $\begin{array}{l}\text { Age at the } \\
\text { first oestrus } \\
\text { occurrence } \\
\text { (days) }\end{array}$ & $\begin{array}{l}\text { Sexual activity } \\
\text { during the first } \\
\text { oestrus (pts) }\end{array}$ & $\begin{array}{l}\text { Age at the } \\
\text { second oestrus } \\
\text { occurrence (days) }\end{array}$ & $\begin{array}{l}\text { Sexual activity } \\
\text { during the second } \\
\text { oestrus (pts) }\end{array}$ & $\begin{array}{l}\text { Age at the } \\
\text { third oestrus } \\
\text { occurrence } \\
\text { (days) }\end{array}$ \\
\hline $\mathrm{D}_{1}$ & $178.2^{\mathrm{A}, \mathrm{a}} \pm 8.32$ & 2.2 & $199.0^{\mathrm{A}, \mathrm{a}} \pm 8.33$ & $\begin{array}{l}\text { Sexual activity } \\
\text { during the third } \\
\text { oestrus (pts) }\end{array}$ \\
$\mathrm{D}_{2}$ & $182.1^{\mathrm{A}, \mathrm{b}} \pm 9.53$ & 2.1 & $203.2^{\mathrm{A}, \mathrm{b}} \pm 9.29$ & 2.4 & $219.9^{\mathrm{A}} \pm 8.48$ & 2.6 \\
$\mathrm{~K}$ & $186.9^{\mathrm{B}} \pm 10.11$ & 2.0 & $208.1^{\mathrm{B}} \pm 10.47$ & 2.2 & $22.5 \pm 9.40$ & 2.4 \\
\hline
\end{tabular}

AB differences significant at $P<0.01 ;{ }^{\text {ab }}$ differences significant at $P<0.05$.

1 point - the gilts manifest oestrus faintly, react to the boar and to the mounting attempt for about $5 \mathrm{~s}$.

After the onset of the second and third oestrus the gilts were weighed and the thickness of the fat layer was measured using a Renco PREG-ALERT apparatus: I - above the scapula; II - behind the last rib $3 \mathrm{~cm}$ from the back line; III - behind the last rib $8 \mathrm{~cm}$ from the back line; and IV - on the lumbar region. After the standing reflex was identified, blood was collected from the marginal ear vein to determine the level of the oestrus hormone 17- $\beta$-estradiol. The concentration of the hormone was determined by radioimmunoassay using a SORIN Biomedica RIA kit (SORIN Biomedica, Milano, Italy). The results obtained were analysed statistically using one-way analysis of variance (group effect). Differences between means were tested by means of Duncan's test.

\section{Results and discussion}

The first oestrus occurred earliest in the experimental gilts (group $\mathrm{D}_{1}$ ) at an average age of 178.2 days, i.e. 8.7 days earlier than in the control group (Table 3 ). Statistically significant $(P<0.01)$ differences were noted between the experimental groups and the control. These differences also applied to reproductive maturity (the second or third oestrus). In gilts from the experimental groups the second oestrus occurred on average on day 201.1, and the third oestrus on day 222.2. During the first oestrus the gilts exhibited low sexual activity, from 2.0 points in the control group to 2.2 in group $\mathrm{D}_{1}$. In subsequent oestruses the gilts' sexual activity increased. It was highest in the gilts from group $\mathrm{D}_{1}$ during the third oestrus, at 2.6 points. Analysis of the $17-\beta$-estradiol level in the blood serum of the experimental gilts showed that the feed rations containing naked oats had a beneficial effect on the secretion of this hormone (Table 4). Its concentration was the highest $-34.1 \mathrm{pg} \mathrm{mL}^{-1}$ - in blood taken from the gilts in experimental group $\mathrm{D}_{1}$ during the third oestrus of the first reproductive cycle, and lowest $-31.8 \mathrm{pg} \mathrm{mL}^{-1}-$ in the blood of the control gilts entering the second oestrus of the first reproductive cycle. The body condition and fat reserves of gilts at first service influence the length of their reproductive life. The mean thickness of fat tissue was highest in the $\mathrm{D}_{1}$ gilts, ranging from 1.56 to $1.77 \mathrm{~cm}$ depending on the oestrus (sec-
Table 4. Concentration of estradiol in blood serum of gilts in the second (II) and third (III) oestrus.

\begin{tabular}{|c|c|c|c|}
\hline Oestrus & Group & $n$ & $17-\beta$-estradiol, pg mL ${ }^{-1}$ \\
\hline \multirow{3}{*}{ II } & $\mathrm{D}_{1}$ & 60 & $33.5^{\mathrm{A}} \pm 1.82$ \\
\hline & $\mathrm{D}_{2}$ & 60 & $32.9^{\mathrm{A}} \pm 1.73$ \\
\hline & $\mathrm{K}$ & 60 & $31.8^{\mathrm{B}} \pm 1.90$ \\
\hline \multirow{3}{*}{ III } & $\mathrm{D}_{1}$ & 30 & $34.1^{\mathrm{a}} \pm 1.75$ \\
\hline & $\mathrm{D}_{2}$ & 30 & $33.9 \pm 1.80$ \\
\hline & $\mathrm{K}$ & 30 & $33.1^{\mathrm{b}} \pm 1.79$ \\
\hline
\end{tabular}

ond or third) (Table 5). These values differed significantly $(P<0.01)$ from the thickness of the fat layer in the control.

A very important problem in reproduction is the failure of females to manifest their readiness and ability to copulate, which delays the age at which the first oestrus occurs. Gilts attain sexual maturity at the age of 5-7 months, depending on genetic and environmental factors. Sinclair et al. (2001) report that Swedish Landrace gilts attain sexual maturity at the age of 173 days. According to Klocek (1997), sexual maturity is attained earliest by gilts kept in groups and allowed to use a paddock (183 days), and latest in those housed individually with no paddock (198 days). Reproductive maturity in gilts depends on body weight and on the degree of development of the reproductive system, and is closely linked to the maturation of a certain number of ovarian follicles and distinct manifestation of oestrus (Stasiak, 1996; Rekiel, 2002). Thus the results obtained in the present study concerning the age at which the first oestrus occurred can be considered optimal. The addition of naked oats to the feed rations led to earlier oestrus in the gilts and had a beneficial effect on their sexual maturity (the occurrence of the second and third oestrus). The gilts' sexual activity depended on the proportion of naked oats in the diet and increased in successive oestruses. The gilts from the experimental groups clearly manifested oestrus and reacted longer to the boar and the mounting attempt.

The level of 17- $\beta$-estradiol intensifies symptoms of oestrus, during which oestrogen attains its highest level in the 
Table 5. Backfat thickness in gilts during the second and third oestrus.

\begin{tabular}{cccccccc}
\hline Oestrus & Group & $n$ & \multicolumn{5}{c}{ Backfat thickness $(\mathrm{cm})$} \\
\cline { 3 - 7 } & & & Measurement 1 & Measurement 2 & Measurement 3 & Measurement 4 & Mean of 4 measurements \\
\hline \multirow{4}{*}{ II } & $\mathrm{D}_{1}$ & 60 & 2.19 & 1.64 & 1.28 & 1.12 & $1.56^{\mathrm{A}} \pm 0.32$ \\
& $\mathrm{D}_{2}$ & 60 & 2.06 & 1.47 & 1.16 & 1.02 & $1.43 \pm 0.29$ \\
& $\mathrm{~K}$ & 60 & 1.93 & 1.41 & 1.08 & 0.98 & $1.35^{\mathrm{B}} \pm 0.28$ \\
\hline \multirow{4}{*}{$\mathrm{III}$} & $\mathrm{D}_{1}$ & 30 & 2.36 & 1.91 & 1.46 & 1.33 & $1.77^{\mathrm{A}} \pm 0.41$ \\
& $\mathrm{D}_{2}$ & 30 & 2.31 & 1.68 & 1.32 & 1.17 & $1.62 \pm 0.38$ \\
& $\mathrm{~K}$ & 30 & 2.06 & 1.54 & 1.23 & 1.13 & $1.49^{\mathrm{B}} \pm 0.33$ \\
\hline
\end{tabular}

$n$ : number of evaluated gilts; ${ }^{\mathrm{AB}}$ differences significant within groups of gilts in the second or third oestrus at $P<0.01$.

blood one day before the appearance of external symptoms (Stasiak, 1996; Belstra et al., 1999; Willenburg et al., 2004). The use of naked oats in the gilts' feed caused synthesis of 17 - $\beta$-estradiol to increase in the gilts; its level was higher than the values obtained in studies by Lechowski (2009) and Stasiak (1996). Oestrogens, including 17- $\beta$-estradiol, regulate ovarian activity and have a luteotropic effect. Jiao et al. (1992) found that the content of this hormone in the organism of the sow was correlated with the size of ovulation and the gonadotropin luteinizing hormone surge prior to ovulation.

Feeding gilts with mixtures containing naked oats caused a beneficial increase in the thickness of the fat layer. Many authors (Whittemore et al., 1995; Sinclair et al., 1998) have found that a fat layer whose thickness exceeds $16 \mathrm{~mm}$ leads to good reproductive results. High-calorie flush feeding a few days before oestrus appears in gilts has a beneficial effect on the intensity of ovulation (Hoffmann, 1994; Van den Brand et al., 2001).

In conclusion, the use of naked oats in gilts' feed rations was observed to have a beneficial effect on their sexual activity and fat cover. Gilts from the experimental groups fed mixtures with $40 \%\left(\mathrm{D}_{1}\right)$ and $20 \%\left(\mathrm{D}_{2}\right)$ naked oats attained sexual and reproductive maturity at a statistically significantly earlier age, and very distinctly manifested oestrus in comparison with the control group.

Edited by: S. Maak

Reviewed by: three anonymous referees

\section{References}

AOAC: Official Methods of Analysis, 17th ed., AOAC International, Gaithersburg, MD, USA, 2000.

Belstra, B. A., Diekman, M. A., Singleton, W. L., and Richert, B. T.: Effect of Lactation Length and Steroid Hormone Treatment on Embryonic Survival and Peripheral Steroid Concentrations in Multiparous Sows, Purdue University Swine Day Reports 1999, 7-19, 1999.

Cronin, G. M., Hemsworth, P. H., Winfield, C. G., Muller, B., and Chamley, W. A.: The incidence of, and factors associated with, failure to mate by 245 days of age in the gilt, Anim. Reprod. Sci., 5, 199-205, 1983.

Evans, A. C. O. and O'Doherty, J. V.: Endocrine changes and management factors affecting puberty in gilts, Livest. Prod. Sci., 68, $1-12,2001$.

Fiske, C. H. and Subbarow, Y.: The colorimetric determination of phosphorus, J. Biol. Chem., 66, 375-400, 1925.

Gordon, I.: Reproductive technologies in farm animals, CABI Publ., Wallingford, Oxfordshire, UK, 2004.

Hemsworth, H. P.: Sow fertility. Refresher Course of Veterinarians, Pig Prod., 95, 791-801, 1987.

Hoffmann, L.: [Proposal for the introduction of an energetic feed evaluation system for all domestic animals based in uniform parameters and principles. 2. Energetic feed evaluation for swine], Arch. Tierernahrung, 46, 237-254, 1994 (in German).

Jiao, S. X., Wang, R. X., Cai, Z. H., Zhao, S. J., and Liao, S. R.: Serum profiles of five reproductive hormones during the first estrous cycle in Fengjing and Landrace gilts, Acta Vet. Zootech. Sinica (Chinese J. Anim. Vet. Sci.), 23, 202-206, 1992.

Klocek, C.: [Effect of keeping method of sows on the formation of the size of ovulation, embryo survival and perinatal mortality of piglets], Doctoral thesis, Zeszyty Naukowe AR w Krakowie, Rozprawy Nr. 223, 1997 (in Polish).

Kosieradzka, I. and Fabijańska, M.: Comparison of the nutritive value of naked and husked oat protein with wheat and maize, J. Anim. Feed. Sci., 10 (Suppl.), 309-314, 2001.

Lechowski, J.: [Evaluation of the effectiveness of ascorbic acid addition to feed on reproductive characteristics of young gilts and insemination boars and the physical and chemical properties of meat fattening], Doctoral thesis, Rozprawy Naukowe Nr. 334, Uniwersytet Przyrodniczy w Lublinie, 2009 (in Polish).

Levis, D. G.: Housing and management aspects influencing gilt development and longevity: A review, in: Proceedings of the 2000 Allen D. Leman Swine Conference, edited by: Scruton, W. C. and Claas, S., 117-131, 2000.

Mazur, A. and Stasiak, A.: [Analysis of the results of the reproductive performance and body weight changes of sows during the first reproductive cycle fed with mixture containing hulled oat grain], Annales UMCS, Sectio EE: Zootechnica, 24, 133-139, 2006 (in Polish).

Normy Żywienia Świń. Wartość pokarmowa pasz: [Swine Feeding Standards]. Instytut Fizjologii i Żywienia Zwierząt im. Jana Kielanowskiego PAN, Jabłonna, Poland, 1993 (in Polish). 
Peltoniemi, O. A. T., Tast, T., Virolainen, J. V., Karkamo, V., Heinonen, M., and Andersson, M. A.: Night-time Melatonin Secretion and Seasonally Delayed Puberty in Gilts, Reprod. Domest. Anim., 40, 224-227, 2005.

Peterson, D. M.: Oats Antioxidants, J. Cereal. Sci., 33, 115-129, 2001.

Petkov, K., Piech, M., Lubowicki, R., Łukaszewski, Z., Jaskowska, I., and Biel, W.: [Assessment of the feed value of hulled and naked oats grains in the feeding of pigs], Rocz. Nauk. Zoot., 28, 165-174, 2001 (in Polish).

Piech, M., Maciorowski, R., and Petkov, K.: [The yield of grain and nutritive components of naked and hulled oats cultivated at two nitrogen levels], Biul. IHAR, 229, 103-113, 2003 (in Polish).

Pisulewska, E., Witkowicz, R., and Borowiec, F.: [The influence of tillage on yield and content and fatty acid composition of naked oats], Żywność Nauka Technologia Jakość, (Suppl.) 6, 240-245, 1999 (in Polish).

Pisulewska, E., Tobiasz-Salach, R., Witkowicz, R., Cieślik, E., and Bobrecka-Jamro, D.: [Effect of habitat conditions on content and quality of lipids in selected oat forms], Żywność Nauka Technologia Jakość, 18, 66-77, 2011 (in Polish).

Rekiel, A.: [The influence of different techniques of drying up on the level of fat reserves and reproductive performance of sows], Doctoral thesis, Rozprawy Naukowe i Monografie Nr. 246, Skoła Główna Gospodarstwa Wiejskiego w Warszawie, 2002 (in Polish).

Sinclair, A. G., Cia, M. C., Edwards, S. A., and Hoste, S.: Response to dietary protein during lactation of Meishan synthetic, Large White and Landrace gilts given food to achieve the same target backfat level at farrowing, Anim. Sci., 67, 349-354, 1998.
Sinclair, A. G., Bland, V. C., and Edwards, S. A.: The influence of gestation feeding strategy on body composition of gilts at farrowing and response to dietary protein in a modified lactation, J. Anim. Sci., 79, 2397-2405, 2001.

Stasiak, A.: [The interdependence of the sexual activity of gilts in heat with the development of reproductive organs and fertility potential and actual], Habilitation thesis, Rozprawy Naukowe 192, Akademia Rolnicza w Lublinie, 1996 (in Polish).

Stasiak, A., Walkiewicz, A., Kamyk, P., and Dziura, J.: [Characteristics of reproduction organs and potential fertility of gilts fed with Avena nuda share], Zesz. Nauk. PTZ, 48, 23-28, 2000 (in Polish).

Van den Brand, H., Langendijk, P., Soede, N. M., and Kemp, B.: Effects of postweaning dietary energy source on reproductive traits in primiparous sows, J. Anim. Sci., 79, 420-426, 2001.

Whittemore, C. T., Etienne, M., and Dourmad, J. Y.: Reproduction in primiparous sows: Nutrition and body condition in relation to productivity, in: Book of Abstracts of the 46th Annual Meeting of the EAAP, edited by: van Arendonk, J. A. M., Prague, Czech Republic, p. 331, 1995.

Willenburg, K. L., Knox, R. V., and Kirkwood, R. N.: Effects of estrogen formulation and its site of deposition on serum PGFM concentrations, uterine contractility, and time of ovulation in artificially inseminated weaned sows, Anim. Reprod. Sci., 80, 147 156, 2004. 